\title{
Effect of Fractionated Irradiation on the Hippocampus in an Experimental Model
}

\author{
Vplyv frakcionovaného ožiarenia na hipokampus \\ v experimentálnom modeli
}

\author{
Balentova S. ${ }^{1}$, Hajtmanova E. ${ }^{2}$, Filova B. ${ }^{3}$, Borbelyova V. ${ }^{4}$, Lehotsky J. ${ }^{5}$ \\ 1 Institute of Histology and Embryology, Jessenius Faculty of Medicine, Comenius University in Bratislava, Martin, Slovak Republic \\ 2 Department of Radiotherapy and Oncology, Martin University Hospital, Martin, Slovak Republic \\ ${ }^{3}$ Institute of Medical Physics, Biophysics, Informatics and Telemedicine, Faculty of Medicine, Comenius University in Bratislava, Slovak Republic \\ ${ }^{4}$ Institute of Molecular Biomedicine, Faculty of Medicine, Comenius University in Bratislava, Slovak Republic \\ ${ }^{5}$ Institute of Medical Biochemistry, Jessenius Faculty of Medicine, Comenius University in Bratislava, Martin, Slovak Republic
}

\begin{abstract}
Summary
Background: lonizing radiation induces altered brain tissue homeostasis and can lead to morphological and functional deficits. The aim of the present study was to investigate the short-term and long-term effect of ionizing radiation on cell population resides adult rat hippocampus. Materials and Methods: Adult male Wistar rats received whole-brain irradiation with fractionated doses of gamma rays (a total dose of $20 \mathrm{~Gy}$ ) and were investigated 30 and 100 days later. A combination of Fluoro-Jade C histochemistry for visualization of degenerating neurons, immunohistochemistry for detection of astrocytes and confocal microscopy were used to quantify the neurodegenerative changes in the hippocampal dentate gyrus and CA1 subfield. Results: A significant increase of Fluoro-Jade C labelled neurons was seen in both of investigated areas through the whole experiment, predominantly 30 days after irradiation. Non-significant decrease of GFAP-immunoreactive astrocytes was found in the hippocampal dentate gyrus and CA1 subfield until 100 days after irradiation. Conclusion: Our recent results showed that radiation response of cell types resides the adult hippocampus may play contributory role in the development of adverse radiation-induced late effects.
\end{abstract}

Key words

radiation dosage - dose fractionation - rat - hippocampus - Fluoro-Jade C - GFAP

\section{Súhrn}

Východiska: Ionizujúce žiarenie ovplyvňuje tkanivovú homeostázu a môže viest' k jeho morfologickému a funkčnému poškodeniu. Ciel'om štúdie bolo skúmat' krátkodobé a dlhodobé účinky ionizujúceho žiarenia na populáciu buniek osidlujúcu hipokampus dospelého potkana. Materiál a metódy: Dospelým samcom potkanov kmeňa Wistar sme ožiarili cranium frakcionovanou dávkou gama žiarenia (celková dávka bola 20 Gy) a vyšetrovali 30 a 100 dní po expozícii. Pomocou histochemickej metodiky Fluoro-Jade $C$ na dôkaz degenerujúcich neurónov, imunohistochemického farbenia na detekciu astrocytov a konfokálnej mikroskopie sme kvantitatívne hodnotili neurodegeneratívne zmeny v gyrus dentatus a oblasti CA1 hipokampu. Výsledky: $\checkmark$ obidvoch vyšetrovaných oblastiach sme zistili signifikantný nárast počtu Fluoro-Jade $C$ značených neurónov, predovšetkým v skupine prežívajúcej 30 dní po ožiarení. Počet GFAP-imunoreaktívnych astrocytov sa počas celého experimentu znižil len nepatrne. Záver: Naše súčasné výsledky poukazujú na to, že postradiačná odpoved' populácie buniek, ktorá tvorí hipokampus môže zohrávat' úlohu vo vývoji neskorých postradiačných prejavov, ktoré sú z hladiska prognózy vel'mi nepriaznivé.

Klúčové slová

ionizujúce žiarenie - dávka žiarenia - potkan - hipokampus - Fluoro-Jade C - GFAP
This work was supported by project 'Center of translational medicine'/'Creating a new diagnostic algorithm for selected cancer dis eases', ITMS: 26220220021 co-financed from EU sources and European Regional Development Fund.

Práca bola financovaná z projektu Centrum translačnej medicíny/Vytvorenie nového diagnostického algoritmu pri vybraných nádorových ochoreniach, ITMS: 26220220021 spolufinancovanými zo zdrojov Eú a Európskeho fondu regionálneho rozvoja.

The authors declare they have no potential conflicts of interest concerning drugs, products, or services used in the study.

Autoři deklarují, že $v$ souvislosti s predmětem studie nemají žádné komerční zájmy.

The Editorial Board declares that the manuscript met the ICMJE "uniform requirements" for biomedical papers.

Redakční rada potvrzuje, že rukopis práce splnil ICMJE kritéria pro publikace zasílané do biomedicínských časopisů.

Sona Balentova, DVM., Ph.D. Institute of Histology and Embryology Jessenius Faculty of Medicine in Martin

Comenius University in Bratislava

Malá Hora 4

03601 Martin

Slovak Republic

e-mail: balentova@jfmed.uniba.sk

Submitted/Obdržané: 8. 3. 2015

Accepted/Prijaté: 5. 4. 2015

http://dx.doi.org/10.14735/amko2015191 


\section{Backgrounds}

The hippocampus is a brain structure which belongs to the limbic system and lies under the medial temporal lobe, one on each side of the brain. It is grouped with other adjacent structures, including the dentate gyrus (DG), subiculum and entorhinal cortex forming a structure called the hippocampal formation. The hippocampus is associated mainly with long-term memory and plays an important role in spatial navigation. Animal experiments investigating the effects of hippocampal damage have previously suggested that the damage causes hyperactivity and may affect the ability to inhibit responses that have previously been learned.

The subgranular zone (SGZ) is one of the two brain regions, where neural stem cells continuously self-renew and differentiate into neurons in a process called neurogenesis. SGZ is a narrow layer of cells located between the granule cell layer (GCL) and hilus of the DG. Progenitor cells of the SGZ migrate into adjacent GCL where they establish mature morphological and functional characteristics [1].

As a region of ongoing neurogenesis, the SGZ of the hippocampal DG is sensitive to therapeutic doses of radiation. Fractionated whole-brain irradiation initiate vascular structural changes, microglial activation, enhanced expression of astrocytes, loss of oligodendrocyte type 2 astrocyte (O-2A), high expression of inflammation-related molecules (cyclooxygenase - Cox, intercellular adhesion molecule-1 - ICAM-1, tumor necrosis factor alpha - TNFa), changes in expression of several immediate-early genes (IEG), reduced expression of glutamatergic $\mathrm{N}$-methyl-D-aspartic acid (NMDA) receptor subunits up to six months post-irradiation [2-8] and ultimately led to tissue necrosis [9]. These changes have been associated with cognitive deficits i.e., the deficits in learning, memory, and spatial information processing ability.

In the present study, we investigated the short-term and long-term effect of fractionated irradiation (total dose of $20 \mathrm{~Gy}$ ) on distribution of cell-specific types housed the hippocampus of rats, survived 30 and 100 days after exposure.

\section{Materials and methods}

Animals

Adult Wistar male rats $(n=26)$ (Velaz, Prague, Czech Republic) 3-4 months old at the start of the experiment and weighing approximately $368 \mathrm{~g}$ were used in this study. The animals were housed in a climate controlled conditions (temperature of $22-24{ }^{\circ} \mathrm{C}$, light - controlled environment with $12 / 12$ hours light/dark cycle). The methods for animals use were approved by the Animal Care and Use Committee, Jessenius Faculty of Medicine in Martin, Comenius University in Bratislava, Slovak Republic (EC 1493/2014 for animal experiments).

\section{Irradiation protocol}

For the irradiation procedure, the animals were lightly anesthetized by i.p. injection of ketamine hydrochloride (1-2 $\mathrm{ml} / \mathrm{kg}$ body weight) and by s.c. injection of xylazine hydrochloride $(0.1-0.2 \mathrm{ml} / \mathrm{kg}$ body weight). The rats received whole-brain irradiation using a ${ }^{60} \mathrm{Co}$ source (apparatus TERAGAM 02 UJP, Prague, Czech Republic). Irradiated rats received $20 \mathrm{~Gy}$ of gamma rays $(5 \mathrm{~Gy} \times 4)$ given at seven day intervals and the animals survived $30(n=5)$ and 100 days $(n=8)$ after the last fraction dose. Control animals were euthanized at $30(n=6)$ and 100 days $(n=7)$ after sham irradiation.

\section{Tissue processing}

Animals were overdosed by i.p. injection of ketamine and s.c. injection of xylazine followed by a transcardial perfusion with saline and $4 \%$ paraformaldehyde in $0.1 \mathrm{M}$ phosphate buffer (PB). Brains were removed from the skull, immersed overnight in the same fixative at $4{ }^{\circ} \mathrm{C}$ and placed in $30 \%$ sucrose for 18 hours. Samples were hemisected in the midline, covered with embedding medium (Killik, Bio Optica, Milano, Italy) and immediately frozen by rapid cooling boost in a cryobar (Shannon Cryotome E, Thermo Scientific Waltham, MA, USA). Serial sagittal $30 \mu \mathrm{m}$ frozen sections were cut, collected on lysine coated slides and air-dried.

\section{Cresyl violet staining}

The sections were dehydrated through descending grades of alcohol (95\%,
$70 \%, 50 \%$, resp.) and brought to distilled water. The slides were then immersed in cresyl violet staining solution for 20 minutes and washed again in distilled water. After dehydration through ascending grades of alcohol (50\%, 70\%, $95 \%, 100 \%$, resp.), the sections were immersed two times in xylene solution for 5 minutes each and finally cover-slipped with an Entellan (Merck Millipore, Germany).

\section{Fluoro-Jade C histochemistry}

The slides were first oven dried for $30 \mathrm{mi}-$ nutes at $55{ }^{\circ} \mathrm{C}$, then rinsed in ethanol (100\%, 70\%, resp.), distilled water and incubated in $0.06 \% \mathrm{KMnO}_{4}$ for $15 \mathrm{mi}$ nutes. The slides were then transferred for 2 hours to $0.0001 \%$ solution of Fluoro-Jade $C$ dye (Histochem, Jefferson, AR, USA) dissolved in $0.1 \%$ acetic acid vehicle. After rinsing through three changes of distilled water, the slides were cover-slipped with Fluoromount (Serva, Heidelberg, Germany).

\section{Immunohistochemistry}

To minimize non-specific binding of the secondary antibody, sections were incubated for 1 hour at room temperature (RT) in goat blocking solution (10\% goat serum, 1\% BSA, 0.5\% Tween 20 in PBS) and then covered overnight at $4{ }^{\circ} \mathrm{C}$ with mouse anti-glial fibrillary acidic protein, a selective marker for astrocytes (GFAP; $1: 500$, Cell Signaling Technology, Danvers, MA, USA). After rinsing, the sections were incubated for 2 hours at RT with goat anti-mouse secondary antibody labelled with Alexa Fluor 488 or Alexa Fluor 594 (1 : 100, diluted in 0.3\% Triton $\mathrm{X}-100$ and $1 \%$ BSA in PBS, Invitrogen-Molecular Probes, Carlsbad, CA, USA). The nuclei were counterstained with 4',6-Diamidino-2-phenylindole (DAPI) and finally cover-slipped with Fluoromount (Serva). The slides were viewed with an Olympus FluoView FV10i confocal laser scanning microscope (Olympus, Japan), objective of $10 \times$ equipped with Alexa Fluor 488 (excitation: 499 nm; emission: $520 \mathrm{~nm}$ ) or Alexa Fluor 594 (excitation: $590 \mathrm{~nm}$; emission: $618 \mathrm{~nm}$ ) and Olympus BX41N microscope (Olympus). The image capture was performed with Olympus Fluoview FV10-ASW software, 
version 02.01 (Olympus), Quick Photo Micro software, version 2.3 (Promicra, Prague, CR) and further processed in Adobe Photoshop CS3 Extended, version 10.0 for Windows (Adobe Systems, San Jose, (A, USA).
Quantitative image analysis

Cell counting was performed in the hippocampal DG and cornu ammonis 1 subfield (CA1). The green fluorescent somas of Fluoro-Jade C labelled neurons were counted in the stratum pyramidale of the
CA1 subfield and str. granulosum of the DG. The green or red fluorescent somas and processes of GFAP immunoreactive astrocytes (GFAP-IR) were counted in the layers adjacent to principal neuronal layers of the CA1 and DG. The values of
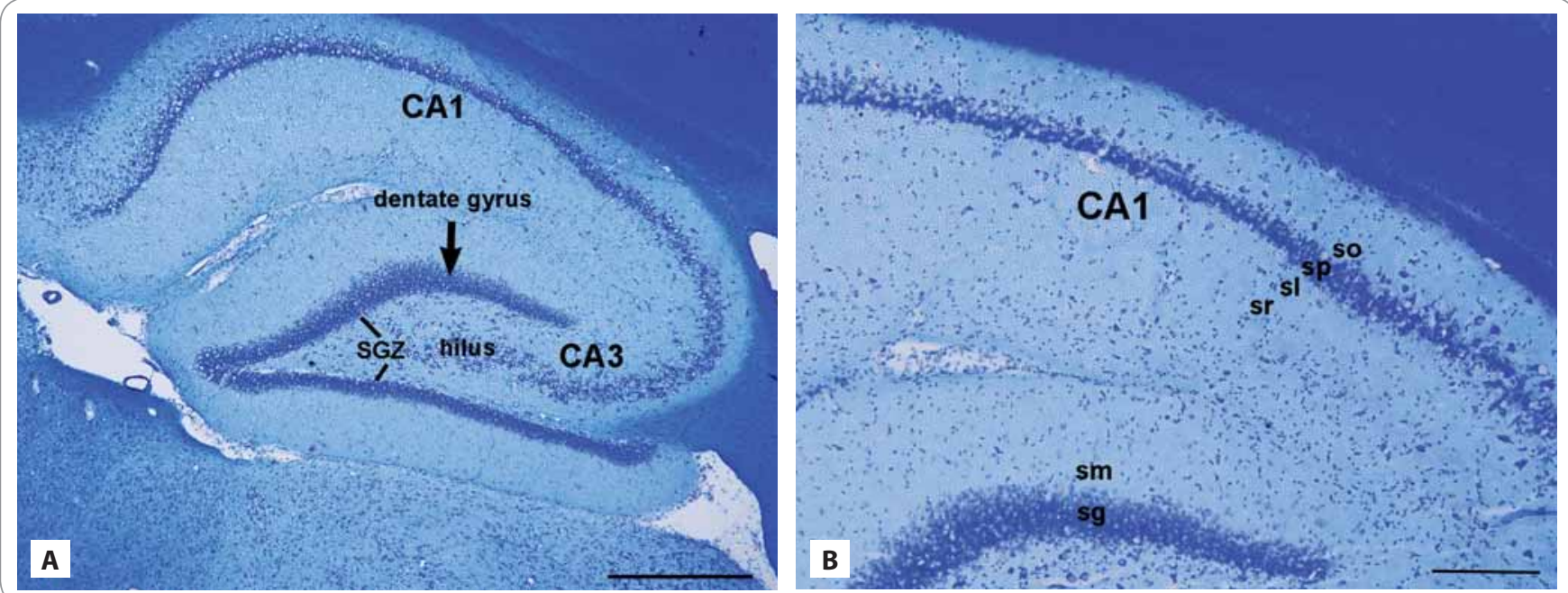

Fig. 1. Cresyl violet stained photomicrographs of the sagittal sections through the hippocampus of adult control rat composed of two regions: the dentate gyrus and subfields of the cornu ammonis region: CA1 and CA3 (A). The lines showed the subgranular zone (SGZ), a narrow layer between stratum granulosum and the hilus. (A) Detail of the CA layers (from inside-out): stratum radiatum (sr), str. lucidum (sl), str. pyramidale (sp), and str. oriens (so) and the DG layers: str. moleculare (sm) and str. granulosum (sg) (B). Scale bars: $A=500 \mu m ; B=200 \mu m$.

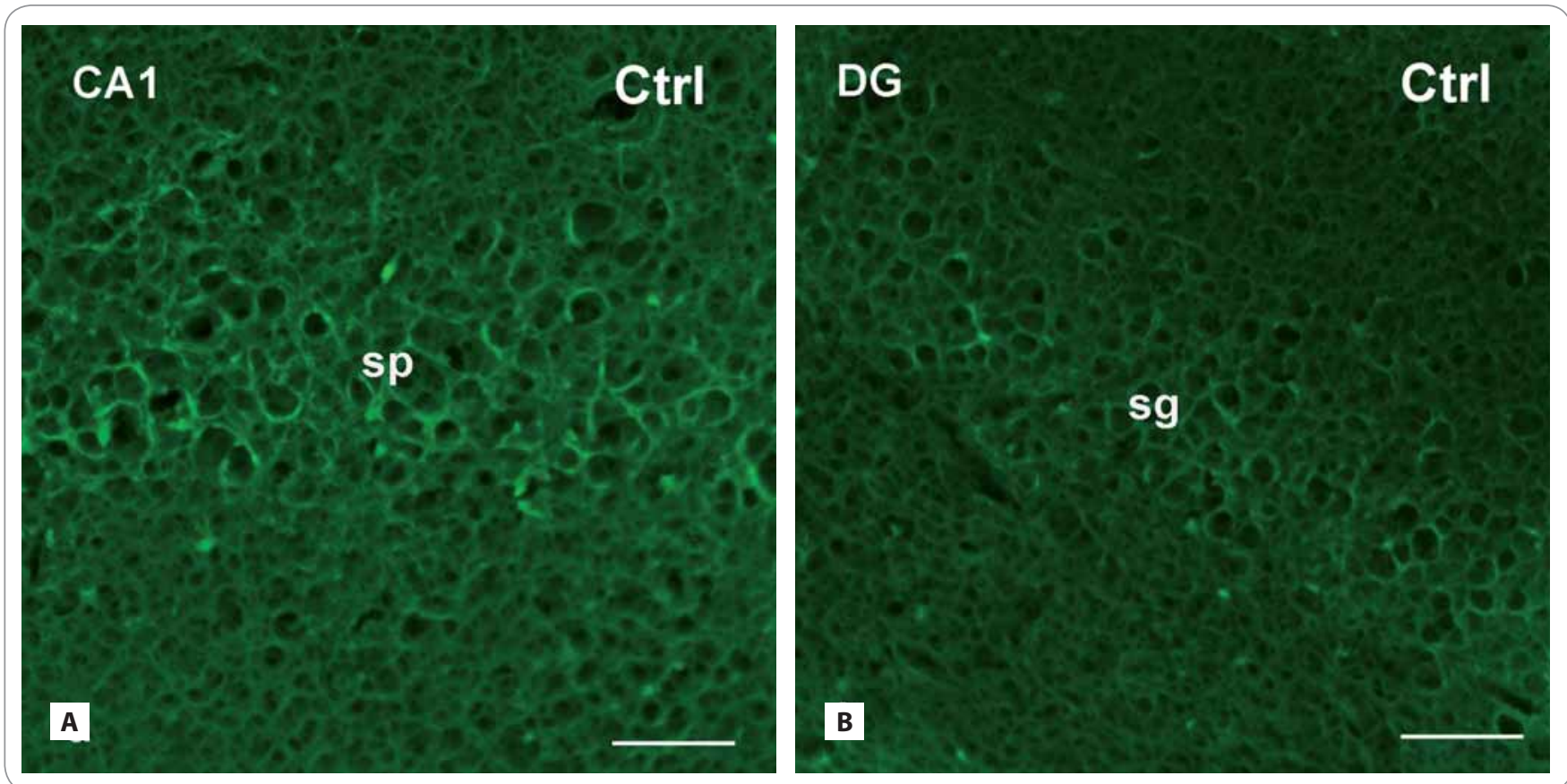

Fig. 2. Photomicrographs of the sagittal sections through the hippocampus of adult rats showing the principal layers of the CA1 subfield and the DG: str. pyramidale (sp) and str. granulosum (sg), resp. Fluoro-Jade C histochemical method for detection of degenerating and dying neurons (green fluorescent somas) in control group (A, B) and in the brain of rats, investigated 30 and 100 days after fractionated irradiation (Irr-30, Irr-100) (C-F) with the total dose of 20 Gy of gamma rays.

Scale bars: $A-F=50 \mu m$. 


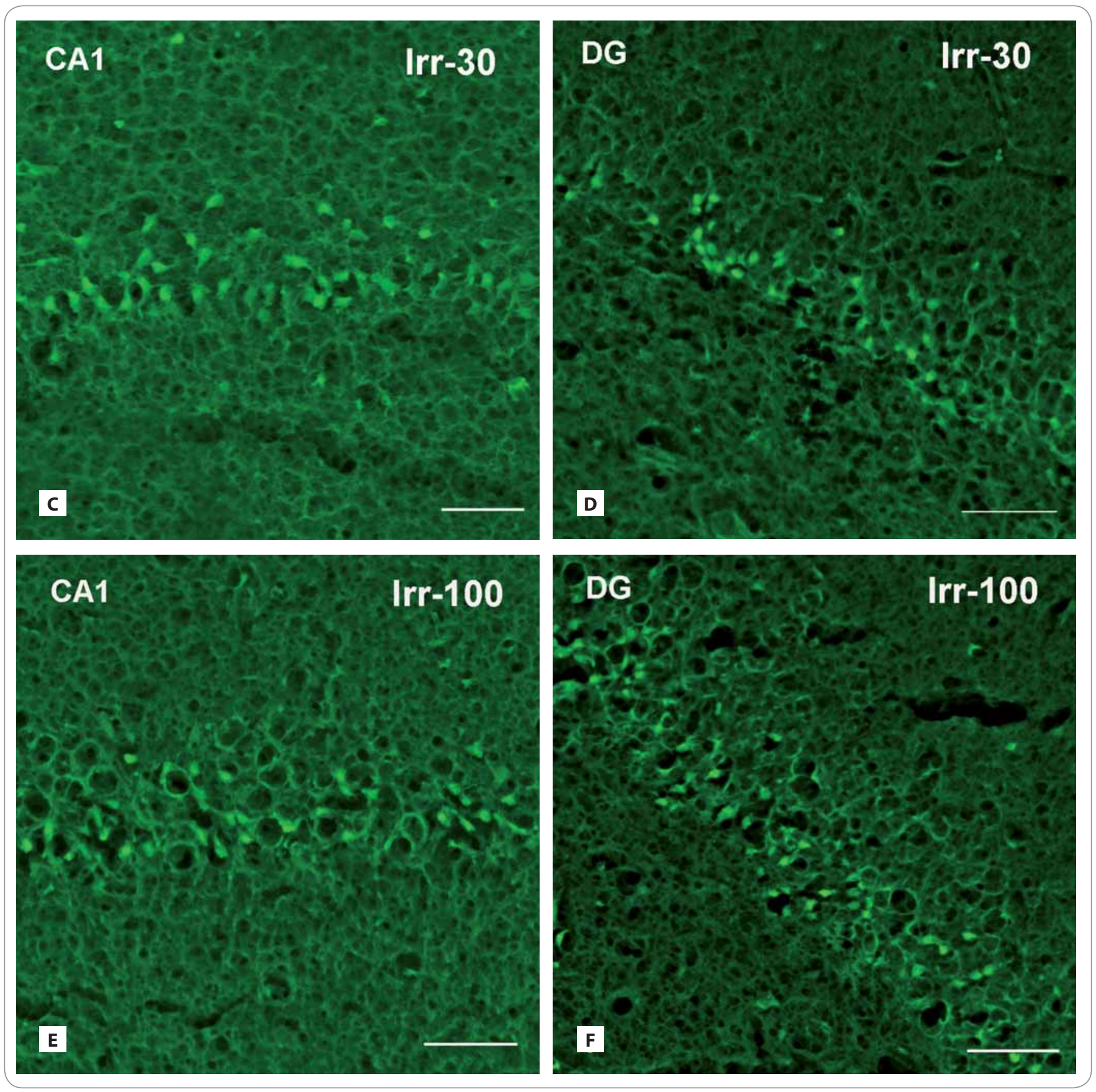

Fig. 2 - continuing. Photomicrographs of the sagittal sections through the hippocampus of adult rats showing the principal layers of the CA1 subfield and the DG: str. pyramidale (sp) and str. granulosum (sg), resp. Fluoro-Jade $C$ histochemical method for detection of degenerating and dying neurons (green fluorescent somas) in control group $(A, B)$ and in the brain of rats, investigated 30 and 100 days after fractionated irradiation (Irr-30, Irr-100) (C-F) with the total dose of 20 Gy of gamma rays.

Scale bars: $A-F=50 \mu m$

GFAP-IR cells counted in all layers were summarized and averaged. The quantitative analysis was performed using ImageJ software (National Institutes of Health, Bethesda, MD, USA), a public domain image processing and analysis program.
Statistical analysis

Data were analyzed using one-way analysis of variance (ANOVA) followed by a Tukey-Kramer test comparison and presented as mean \pm standard error (SEM). Statistical significance was set at $p<0.05$. All analyses were performed using GraphPad Prism software, version 6.01 for Windows (La Jolla, CA, USA).

\section{Results}

Cresyl violet staining

To obtain the basic histology of investigated areas, the Cresyl violet stain- 


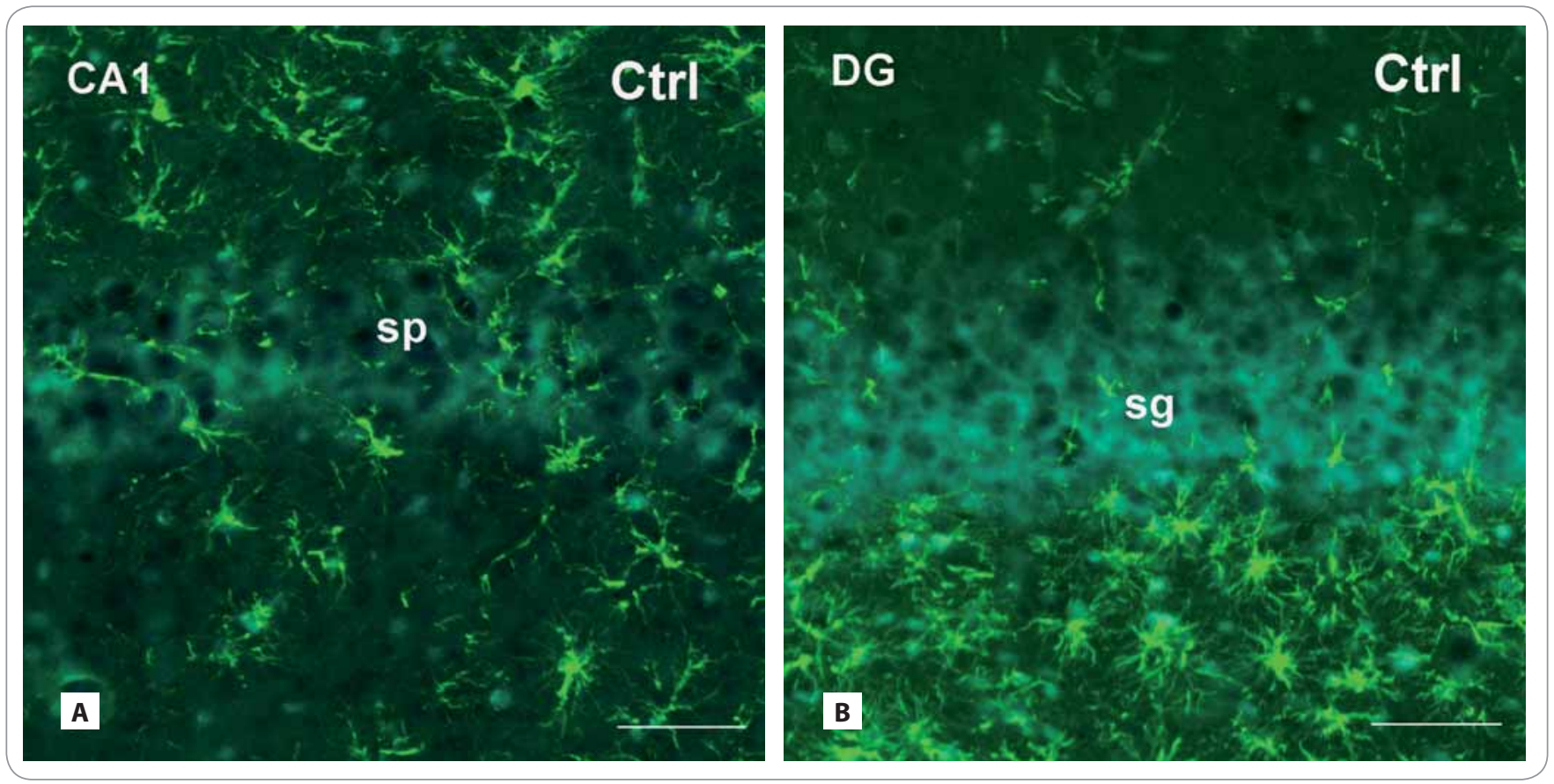

Fig. 3. Photomicrographs of the sagittal sections through the hippocampus of adult rats showing the principal layers of the CA1 subfield and the DG: str. pyramidale (sp) and str. granulosum (sg), resp. immunofluorescent staining for detection of glial fibrillary acid protein (GFAP) (red or green fluorescent somas and processes, counterstained with blue DAPI nuclear dye), marker for mature astrocytes in control group (A, B) and in the brain of rats, investigated 30 and 100 days after fractionated irradiation (Irr-30, Irr-100) (C-F) with the total dose of $20 \mathrm{~Gy}$ of gamma rays.

Scale bars: $A-F=50 \mu \mathrm{m}$.

ing was performed on the sagittal sections taken from control animals. The hippocampus is divided into two regions, the DG and CA. The CA is a curved structure forming a " $U$ " enchased in the DG (Fig. 1A, B). The inside portion of the DG is known as the hilus. The DG and CA are each composed of the main cellular layers: the granule and pyramidal cell layers. From inside-out, the layers or strata of the DG are: the polymorphic layer, the stratum granulosum and str. moleculare. The neurogenic SGZ is a narrow layer of cells located between the GCL and hilus of the DG [10].

From inside-out, the strata of the CA are: the str. moleculare, str. lacunosum, str. radiatum, str. lucidum, str. pyramidale, str. oriens and the alveus. The GCL or str. granulosum of the DG contain the somas of the granule cells and the pyramidal cell layer or str. pyramidale of the CA1 subfield contain triangular-shaped somas of pyramidal neurons. Cresyl violet as a type of a Nissl stain colors the somas of neurons and dendrites, but absent in axons. The Nissl substance (rough endoplasmic reticulum) appears dark blue due to the staining of ribosomal RNA, giving the cytoplasm a granular appearance.

\section{Fluoro-Jade C-labelled neurons}

Population of neurons housed the hippocampal DG and CA1 subfield underwent significant changes in both of treated groups (Fig. 2A-F). Numbers of Fluoro-Jade $C$ labelled neurons increased predominantly in the brains of animals, survived 30 days after irradiation in the str. pyramidale of CA1 (Irr-30: $66.53 \pm 5.24 / \mathrm{cm}^{2}$ vs. Ctrl: no cells; $p<0.001)$. Granular neurons of the DG significantly increased as well (Irr-30: $32.62 \pm 3.9$ vs. Ctrl: no cells; $p<0.001)$. In the brains of rats that survived 100 days after radiation treatment the numbers of Fluoro-Jade $C$ labelled neurons in the CA1 area were significantly lower than in previous treated group (Irr-100: $46.85 \pm 4.88$ vs. Irr-30: $66.53 \pm 5.24 ; p<0.01$ ), however, still higher than control values (Irr-100 vs. Ctrl: no cells; $p<0.001)$. Granule neu- rons of the DG still displayed significant immunoreactivity ( $28 \pm 3.96$ vs. Ctrl: no cells; $p<0.001$ ); however, their overall numbers in both of treated groups were lower than in the CA1 subregion.

\section{GFAP-immunoreactive astrocytes}

In both radiation-treated groups, we found only slight changes in cell density of GFAP-IR astrocytes (Fig. 3A-F). Thirty days after irradiation, there was an expressive decrease in the CA1 subfield $\left(171.86 \pm 54.16 / \mathrm{cm}^{2}\right.$ vs. Ctrl: $\left.347 \pm 55\right)$ and virtually no decrease in the DG ( $226.75 \pm 24.91$ vs. Ctrl: $246.33 \pm 25.17)$. The following group of animals, investigated 100 days after treatment, showed more profound decrease in the CA 1 subfield $(279.83 \pm 64.5)$ than in the DG $(223.60 \pm 46.83)$.

\section{Discussion}

Investigation of brain in course of 100 days after whole-brain fractionated irradiation showed expected massive appearance of Fluoro-Jade C labelled neurons in the principal neuronal layers 

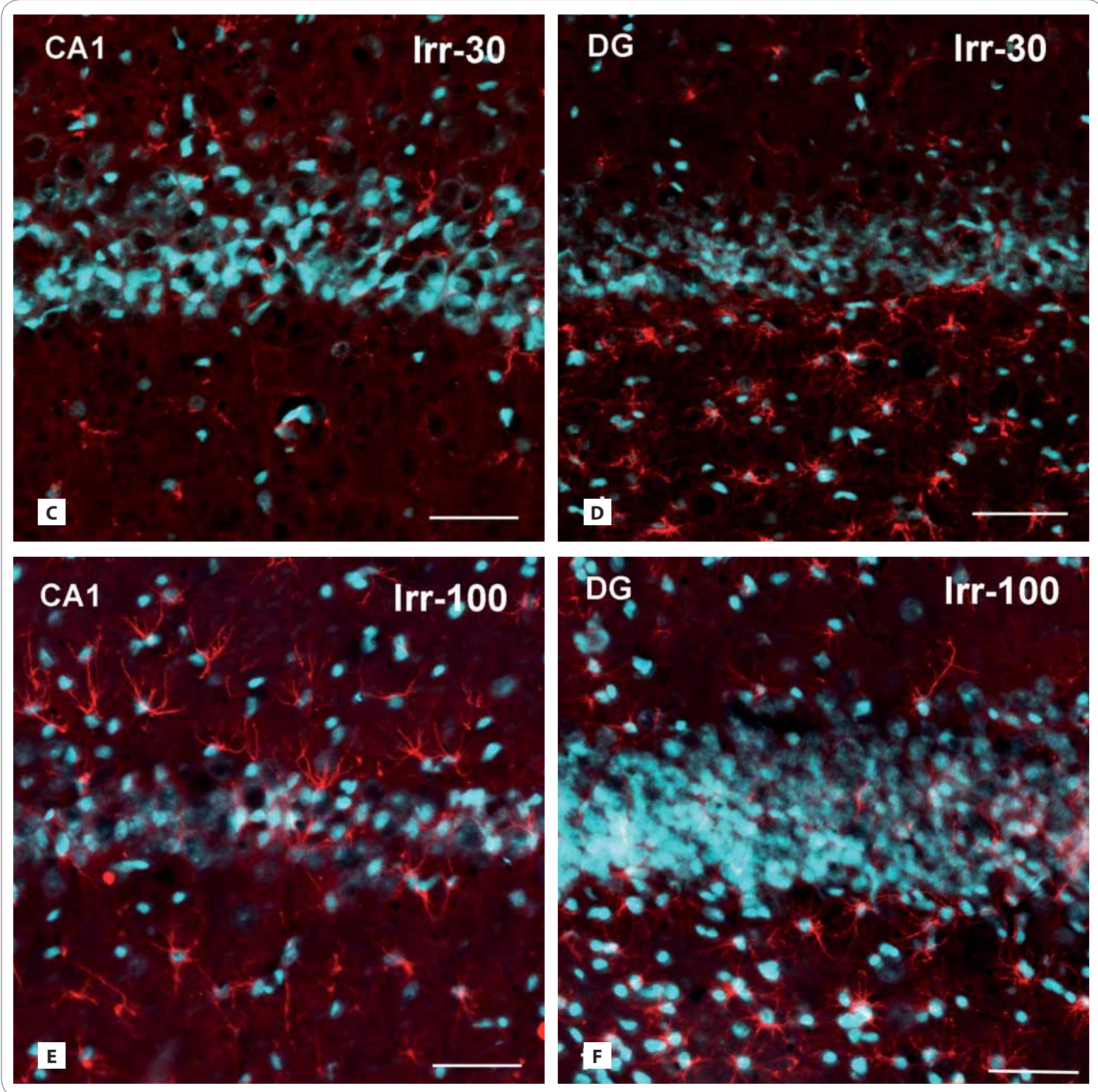

Fig. 3 - continuing. Photomicrographs of the sagittal sections through the hippocampus of adult rats showing the principal layers of the CA1 subfield and the DG: str. pyramidale (sp) and str. granulosum (sg), resp. immunofluorescent staining for detection of glial fibrillary acid protein (GFAP) (red or green fluorescent somas and processes, counterstained with blue DAPI nuclear dye), marker for mature astrocytes in control group (A, B) and in the brain of rats, investigated 30 and 100 days after fractionated irradiation (Irr-30, Irr-100) (C-F) with the total dose of 20 Gy of gamma rays.

Scale bars: $A-F=50 \mu m$.

of the hippocampal DG and CA1 subfield (Graph 1A, B). About 20 years ago, a novel fluorochrome, Fluoro-Jade, was demonstrated to be a high-affinity tracer detecting neuronal degeneration and successfully used at various ex- perimental models of neurotoxic insults [11]. Neurodegenerative changes induced by neurotoxicants (kainic acid, ibogaine, iron and manganese salts etc.) were systematically examined by this fluorochrome [11,12]. The Fluoro-Jade and newer dyes, Fluoro-Jade B and Fluoro-Jade $C$, were found to stain all degenerating neurons regardless of cause of cell death. Fluoro-Jade dyes stains the somas, dendrites, axons and axon terminals of degenerating neurons, but 
A

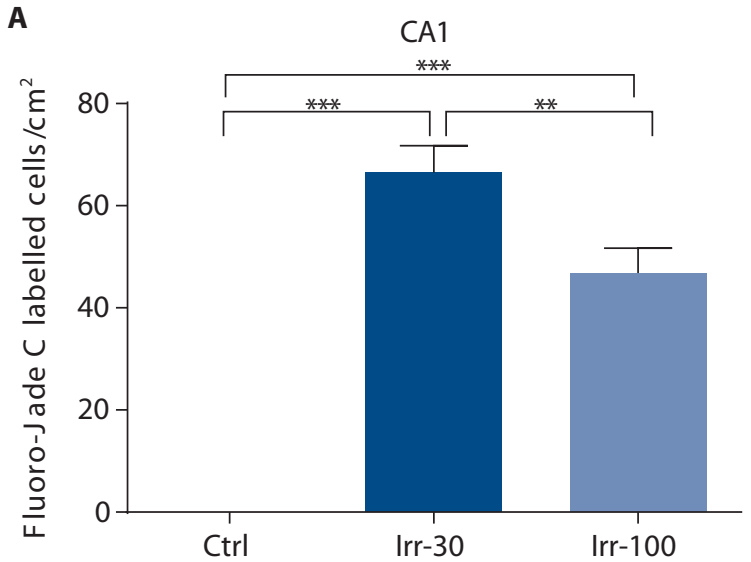

C

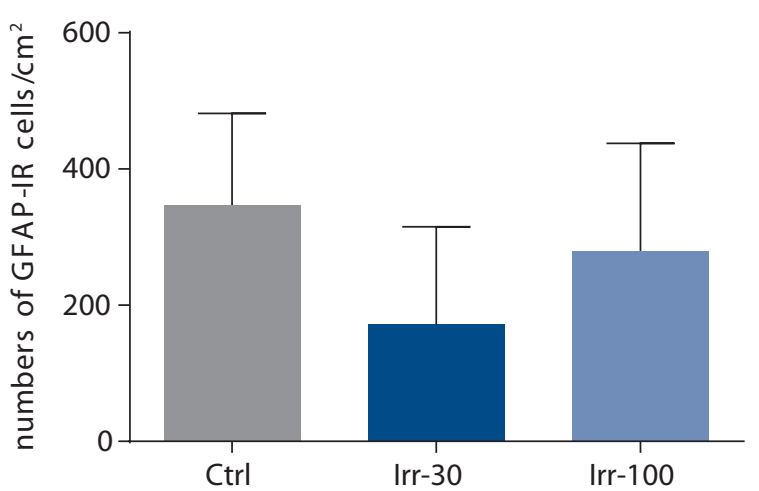

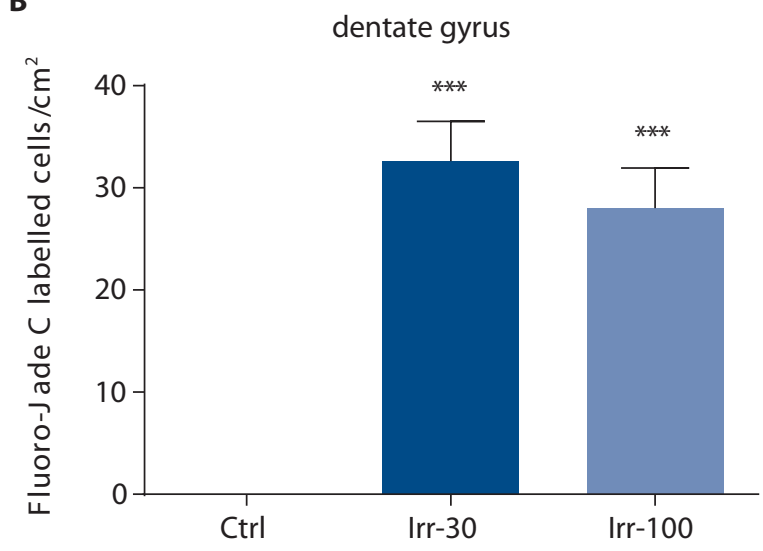

D

dentate gyrus

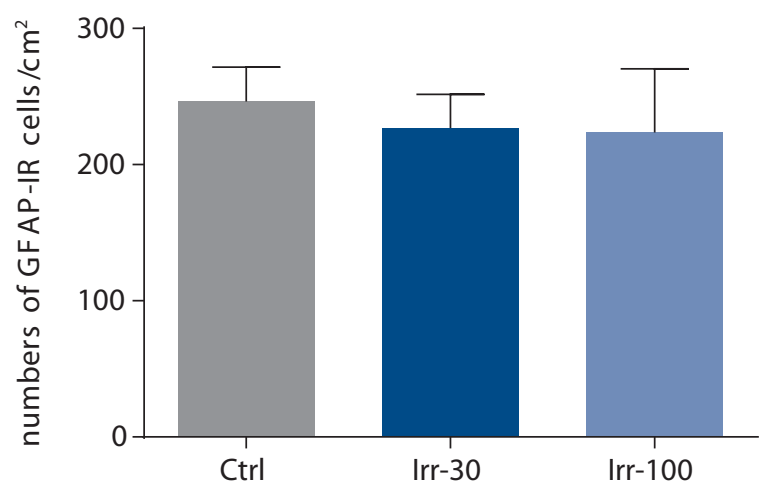

Graph 1. Distribution of Fluoro-Jade C labelled (A, B) and GFAP-immunoreactive (GFAP-IR) (C, D) cells in the hippocampal DG and CA1 subfield of control and irradiated rats investigated 30 and 100 days after fractionated irradiation (Ctrl, Irr-30, Irr-100; $x \pm$ SEM). Statistical significance of differences between control and irradiated group and between the irradiated animals: ${ }^{* *} p<0.01 ;{ }^{* * *} p<0.001$.

do not stain healthy neurons. However, the mechanism by which Fluoro-Jade dyes labels degenerating neurons is unknown. Despite this fact, this relatively simple method is comparable to the traditional methods, such as silver staining.

It is probable that this dye could also label cells undergoing apoptosis, a specialized form of neuronal degeneration. Examination of the relationship between Fluoro-Jade B (FJ-B) positivity and terminal deoxynucleotidyl transferase-mediated dUTP nick end labelling (TUNEL) stained apoptotic cells revealed higher numbers of FJ-B labelled cells then TUNEL labelled cells and only minority of cells displayed colocalization. Since a small fraction of all FJ-B neurons were double-labelled by TUNEL, it is not clear whether a large proportion of re- maining FJ-B-positive/TUNEL-negative cells are in an early phase of apoptosis, or are in fact necrotic [13].

In our experiment, the steep increase in rate of neurodegeneration was more evident in the group investigated 30 days after irradiation. This fact is particularly comparable with our previous finding about increased apoptosis in the neurogenic subvetricular zone-olfactory bulb axis (SVZ-OB axis) of rats investigated up to three months after fractionated irradiation [14]. Experiments done before showed, that single irradiation with various radiation doses (2-10 Gy) dramatically increased the numbers of apoptotic cells in the hippocampal DG 3-6 hours after exposure. Although the extent of apoptosis later decreased, it remained unchanged for 1-9 months after initial exposure [15-20]. Different dynamics of proliferation strongly depends on techniques used for radiation delivery. Cellular response to single exposure is rapid and massive, within hours after treatment, whereas the fractionated response is delayed and surpassed the end of radiation treatment. With a fractionated irradiation application, the first dose attacks predominantly the active proliferating cells and cell death occurs several hours later. Apoptosis is replaced by restoration of mitotic activity as response to cell death, and the subsequent dose kills the cells that began to proliferate either spontaneously or in response to the cell loss of the previous day [21]. Since we did not perform colocalization of proliferating and degenerating cells within the 
hippocampus, we may speculate that lower numbers of dying neurons found 100 days after treatment may represent the recruitment of a relatively quiescent stem cell population [17]. Immunohistochemical staining of proliferative marker Ki-67 in two subfields CA1 and CA3 showed that proliferating cells with neuronal features in the str. pyramidale are susceptible to irradiation [22]. The persistence of dying neurons up to 100 days after treatment revealed a development of radiation-induced late effects. This could be important from the medical perspective since the doses used in radiotherapy of brain tumors are often much larger than the levels needed to eliminate neurogenesis [9]. Recently, the routine use of whole-brain radiation therapy (WBRT) has been highly scrutinized, considering its potential impact on neurocognitive function and quality of life. With the many advances in neurosurgery, imaging, medical oncology, and radiation oncology, the outcomes for some patients have greatly improved [23]. To mitigate the neurocognitive effects of WBRT, [24] the results from the phase III RTOG 0933 trial of hippocampal-avoidance WBRT were reported. Results showed that conformal avoidance of the hippocampus during WBHT is associated with preservation of memory and quality of life of patients as compared to historical control group. Taking into account our unpublished results from behavioral tests and presented histological findings, radiation-induced brain injury was represented by an increase of neuronal degeneration and decrease of neurogenesis. These reductions have been correlated with deficits in hippocampal-dependent spatial learning and memory assessed by the Morris water maze $[18,19]$. Therefore, it is necessary to create hippocampal sparing techniques during brain radiotherapy to minimize potential adverse effect, i.e. worsening of neurocognitive function [23].

In general, immunohistochemical staining provides valuable information in research of normal and pathologically changed cells and tissues [25-27]. In our study, immunohistochemical staining of astrocytes resides the hippocam- pus did not show expressive changes in course of experiment (Graph 1C, D). In both investigated areas, there was a relatively low decrease in the numbers of GFAP-IR cells, more evident at 30 days after treatment. This is in discrepancy with our previously published studies that revealed strong short and long lasting astrocytic response after fractionated irradiation with low overall doses $(3,4$ Gy) $[14,28]$. Brain lesions generally increase SVZ neurogenesis or gliogenesis and cause SVZ cell emigration to ectopic locations [29]. Regarding glial cell fate after radiation treatment, radiation injury can preserve production of glial progenitor cells; however, radiosensitivity seems to be dependent on the cell type. Previous studies reported higher radiosensitivity of oligodendrocytes and astrocytes appeared to be relative resistant [17,30-32]. Several studies reported that radiation causes activation of astrocytes (reactive gliosis) and microglial cells at least six months after fractionated treatment $[2,4,33]$. According to our current findings and results obtained on a similar topic from other laboratories $[4,17,20,34]$ we can speculated, that observed changes seems to be associated rather with a lower radiosensitivity of glial cells. Since this conclusion does not sufficiently explain the reason of such a weak astrocytic response, additional studies need to be performed to determine the presence of pro-inflammatory and anti-inflammatory mediators, which are elevated after brain injury [35].

\section{Conclusion}

Obtained results confirm previous finding about radiation induced neurodegenerative changes in the hippocampal principal neuronal layers and potential risk of development of late pathomorphological and cognitive adverse symptoms. Taking into account that the most important factor in radiation oncology is a dose-tolerance limit for normal tissue to therapeutic radiation, outputs taken from animal studies should be crucial for development of novel therapeutic approaches. Therefore, it is necessary to create prevention strategies to avoid irreversible effects in clinical radiotherapy.

\section{Acknowledgements}

The authors are grateful to colleagues from the Department of Radiotherapy and Oncology of Martin University Hospital for technical assistance with the irradiation. We would like to express our thanks to Mrs. M. Kondekova and Mrs. A. Resetarova for their excellent technical assistance.

\section{References}

1. Kempermann G. Why new neurons? Possible functions for adult hippocampal neurogenesis. J Neurosci 2002; 22(3): 635-638.

2. Cicciarello R, d'Avella D, Gagliardi ME et al. Time-related ultrastructural changes in an experimental model of whole brain irradiation. Neurosurgery 1996; 38(4): 772-779.

3. Gaber MW, Sabek OM, Fukatsu K et al. The differences in ICAM-1 and TNF-a expression between high single fractions and fractionated irradiation in mouse brain. Int J Radiat Biol 2003; 79(5): 359-366.

4. Yuan $\mathrm{H}$, Gaber MW, Boyd K et al. Effects of fractionated radiation on the brain vasculature in a murine model: blood-brain barrier permeability, astrocyte proliferation, and ultrastructural changes. Int J Radiat Oncol Biol Phys 2006; 66(3): 860-866.

5. Rosi S, Andres-Mach M, Fishman KM et al. Cranial irradiation alters the behaviorally induced immediate-early gene arc (activity-regulated cytoskeleton-associated protein). Cancer Res 2008; 68(23): 9763-9770. doi: 10.1158/0008-5472.CAN-08-1861.

6. Wilson CM, Gaber MW, Sabek OM et al. Radiation-induced astrogliosis and blood-brain barrier damage can be abrogated using anti-TNF treatment. Int J Radiat Oncol Biol Phys 2009; 74(3): 934-941. doi: 10.1016/j.ijrobp.2009.02.035.

7. Machida M, Lonart G, Britten RA. Low (60cGy) doses of (56)Fe HZE-particle radiation lead to a persistent reduction in the glutamatergic readily releasable pool in rat hippocampal synaptosomes. Radiat Res 2010; 174(5): 618-623. doi: 10.1667/RR1988.1

8. Zhou H, Liu Z, Liu J et al. Fractionated radiation-induced acute encephalopathy in a young rat model: cognitive dysfunction and histologic findings. AJNR Am J Neuroradiol 2011; 32(10): 1795-1800. doi: 10.3174/ajnr.A2643. 9. Wong CS, Van der Kogel AJ. Mechanisms of radiation injury to the central nervous system: implications for neuroprotection. Mol Interv 2004; 4(5): 273-284.

10. Taupin P. The Hippocampus. In: Taupin P (ed.). The Hippocampus: neurotransmission and plasticity in the nervous system. New York: Nova Science Publishers Inc 2007: 3-6.

11. Schmued LC, Albertson C, Slikker W Jr. Fluoro-Jade: a novel fluorochrome for the sensitive and reliable histochemical localization of neuronal degeneration. Brain Res 1997; 751(1): 37-46.

12. Schmued LC, Hopkins KJ. Fluoro-Jade: novel fluorochromes for detecting toxicant-induced neuronal degeneration. Toxicol Pathol 2000; 28(1): 91-99.

13. Ballok DA, Millward JM, Sakic B. Neurodegeneration in autoimmune MRL-Ipr mice as revealed by Fluoro Jade B staining. Brain Res 2003; 964(2): 200-210.

14. Balentova S, Hajtmanova E, Kinclova I et al. Long-term alterations of cell population in the adult rat forebrain following exposure to fractionated doses of ionizing radiation. Gen Physiol Biophys 2013; 32(1): 91-100. doi: 10.4149/gpb_2013009.

15. Peissner $W$, Kocher $M$, Treuer $\mathrm{H}$ et al. lonizing radiation-induced apoptosis of proliferating stem cells in the dentate gyrus of the adult rat hippocampus. Mol Brain Res 1999; 71(1): 61-68

16. Tada E, Yang C, Gobbel GT. Long-term impairment of subependymal repopulation following damage by ionizing radiation. Exp Neurol 1999; 160(1): 66-77. 
17. Mizumatsu S, Monje LM, Morhardt DR et al. Extreme sensitivity of adult neurogenesis to low doses of X-irradiation. Cancer Res 2003; 63(14): 4021-4027.

18. Raber J, Rola R, Lefevour A et al. Radiation induced cognitive impairments are associated with changes in indicators of hippocampal neurogenesis. Rad Res 2004; 162(1): 39-47.

19. Rola R, Raber J, Rizk A et al. Radiation-induced impairment of hippocampal neurogenesis is associated with cognitive deficits in young mice. Exp Neurol 2004; 188(2): $316-330$

20. Fan Y, Liu Z, Weinstein PR et al. Enviromental enrichment enhances neurogenesis and improves functional outcome after irradiation. Eur J Neurosci 2007; 25(1): 38-46.

21. Wojtowicz JM. Irradiation as an experimental tool in studies of adult neurogenesis. Hippocampus 2006; 16(3): 261-266.

22. Balentova S, Hajtmanova E, Kinclova I et al. Radiation-induced long-term alterations in hippocampus under experimental conditions. Klin Onkol 2012; 25(2): $110-116$

23. Kazda T, Jancalek R, Pospisil P et al. Why and how to spare the hippocampus during brain radiothe- rapy: the developing role of hippocampal avoidance in cranial radiotherapy. Radiat Oncol 2014; 9: 139. doi: 10.1186/1748-717X-9-139.

24. Gondi V, Pugh SL, Tome WA et al. Preservation of me mory with conformal avoidance of the hippocampal neural stem-cell compartment during whole-brain radiotherapy from brain metastases (RTOG 0933): a phase I multi-institutional trial. J Clin Oncol 2014; 32(34): 3810-3816. doi: 10.1200/JCO.2014.57.2909.

25. Adamkov M, Halasova E, Kajo K et al. Survivin: a promising marker in breast carcinoma. Neoplasma 2010; 57(6): 572-577

26. Adamkov M, Halasova E, Rajcani J et al. Relation between expression pattern of p53 and survivin in cutaneous basa cell carcinomas. Med Sci Monit 2011; 17(3): BR74-BR80. 27. Halasova E, Adamkov M, Matakova T et al. Lung cance incidence and survival in chromium exposed individual with respect to expression of anti-apoptotic protein survivin and tumor supressor p53 protein. Eur J Med Res 2010; 15 (Suppl 2): 55-59.

28. Balentova S, Hajtmanova E, Plevkova J et al. Fractionated irradiation-induced altered spatio-temporal cell distribution in the rat forebrain. Acta Histochem 2013; 115(4) 308-314. doi: 10.1016/j.acthis.2012.09.001.
29. Sundholm-Peters NL, Yang HK, Goings GE et al. Subvetricular zone neuroblasts emigrate toward cortical lesions. J Neuropathol Exp Neurol 2005; 64(12): 1089-1100

30. Sano K, Sato M, Tanaka R. Radiation-induced apoptosis and injury of oligodendrocytes on neonatal rat brains. Clin Neurol Neurosur 1997; 99 (Suppl 1): S117.

31. Chow BM, LiYQ, Wong CS. Radiation-induced apoptosis in the central nervous system is p53-dependent. Cell Death Differ 2000; 7(8): 712-720.

32. Kurita $\mathrm{H}$, Kawahara N, Asai A et al. Radiation-induced apoptosis of oligodendrocytes in the adult rat brain. Neurol Res 2001; 23(8): 869-874.

33. Mildenberger M, Beach TG, McGeer EG et al. An animal model of prophylactic cranial irradiation: histological effects at acute, early and delayed stages. Int J Radiat Oncol Biol Phys 1990; 18(5): 1051-1060.

34. Shinohara C, Gobbel GT, Lamborn KR et al. Apoptosis in the subependyma of young adult rats after single and fractionated doses of X-rays. Cancer Res 1997; 57(13): 2694-2702.

35. Hwang SY, Jung JS, Kim TH et al. lonizing radiation induces astrocyte gliosis through microglia activation. Neurobiol Dis 2006; 21(3): 457-467.

\section{SOUTY̌Ž NA PODPORU AUTORSKÝCH TÝMO̊ PUBLIKUJÍĆCH V ZAHRANIČNÍCH ODBORNÝCH TITULECH}

\section{Odměna pro vítěze: 10000 Kč}

\section{Cíl soutěže:}

Podpořit renomé a prestiž časopisu Klinická onkologie - oficiálního časopisu ČOS ČLS JEP - u domácích i zahraničních autorů, lékařu a akademických pracovníků.

\section{Podmínky soutěže:}

1. Soutěž je určena autorským týmům, které publikují v zahraničních odborných titulech.

2. Do soutěže budou zařazeny práce publikované v zahraničních titulech od června 2014 do června 2015.

3. Ve svých článcích zaslaných $\mathrm{k}$ publikaci do zahraničního periodika budou autoři citovat práci, která byla otištěna v časopise Klinická onkologie (k vyhledání lze použit databáze www.pubmed.org nebo www.linkos.cz).

4. Do soutěže nebudou zařazeny autocitace.

5. Ze všech prací, které splní podmínky soutěěe, bude redakční radou vylosována jedna, jejiž autorský tým bude oceněn částkou 10000 Kč.

\section{KLINICKÁ ONKOLOGIE

